\title{
INCIDENTAL MORTALITY OF FRANCISCANA (PONTOPORIA BLAINVILLEI) IN THE ARTISANAL FISHERY OF PRAIA GRANDE, SÃO PAULO STATE, BRAZIL
}

\author{
Carolina P. Bertozzi ${ }^{1}$ and Alexandre N. Zerbini ${ }^{2}$
}

\begin{abstract}
The artisanal fishery in Praia Grande, São Paulo State, southeastern Brazil, was monitored between August 1998 and June 2001 through interviews with fishermen and onboard observations. The objective was to describe the fleet, the gear and the fishing activities, and to monitor the bycatch of small cetaceans. The Praia Grande fishing community has 20 fishermen who operate five aluminum and one wooden open boat. Seven types of gillnet and one beach seine net are used. Nets are made of nylon monofilament; net length and height range from $60-1800 \mathrm{~m}$ and $1.5-10 \mathrm{~m}$, respectively. Mesh sizes vary from $7-30 \mathrm{~cm}$. Each type of net is set up according to target species and weather conditions. Fish of the families Sciaenidae, Carangidae, Carcharhinidae, Trichiuridae and Ariidae are the main species captured. The incidental mortality of 31 franciscanas was recorded. Thirteen specimens were collected: 8 males $(106-122 \mathrm{~cm})$ and 5 females $(71-134 \mathrm{~cm})$. Captures took place in depths of up to $20 \mathrm{~m}$ and along $31 \mathrm{~km}$ of the coast. Catch per unit of effort for the period July 1999-June 2001 indicated a higher mortality in autumn and in gillnets with $14 \mathrm{~cm}$ stretched mesh size ('malha 14') Three franciscanas were captured and released alive from beach seine nets. Several fishing communities with similar operational methods along the southeastern coast of Brazil remain unmonitored. This suggests that franciscana mortality may be substantial on a regional basis and emphasizes the urgency of systematic monitoring.

Resumo - A frota pesqueira artesanal da Praia Grande, litoral central do Estado de São Paulo, sudeste do Brasil, foi monitorada entre agosto de 1998 e junho de 2001 através de entrevistas com pescadores e observações à bordo. O objetivo foi descrever a frota, as artes de pesca, a atividade pesqueira e monitorar a captura acidental de pequenos cetáceos. A comunidade pesqueira de Praia Grande possui 20 pescadores que operam cinco lanchas de alumínio e uma canoa de madeira. Sete tipos de redes de espera e um tipo de rede de arrasto de praia são utilizadas. As redes são confeccionadas com nylon monofilamento; o comprimento e altura das redes varia de $60-1800 \mathrm{~m}$ e $1.5-10 \mathrm{~m}$, respectivamente. O tamanho das malhas varia de 7 a $30 \mathrm{~cm}$. A utilização de cada tipo de rede varia de acordo com a espécie alvo e condições meteorológicas. Peixes das famílias Sciaenidae, Carangidae, Carcharhinidae, Trichiuridae e Ariidae são as principais espécies capturadas. A mortalidade acidental de 31 toninhas foi registrada. Treze espécimes foram coletados: 8 machos (106-122cm) e 5 fêmeas $(71-134 \mathrm{~cm})$. As capturas ocorrem a profundidades máximas de $20 \mathrm{~m}$ e ao longo de $31 \mathrm{~km}$ da costa. A captura por unidade de esforço de pesca do período julho 1999-junho 2001 indicou uma maior mortalidade no outono em redes de espera de fundo com malha de 14cm entre nós esticados ("malha 14"). Três toninhas foram capturadas e liberadas vivas em rede de arrasto de praia. Existem diversas pequenas comunidades pesqueiras não monitoradas com métodos operacionais similares ao longo da costa Sudeste do Brasil. Isto sugere que a mortalidade de toninhas possa ser significativa para a região e destaca a necessidade de monitoramento constante.
\end{abstract}

Keywords: São Paulo, Southeastern Brazil, Incidental Mortality, Fisheries, Gillnets, CPUE, Franciscana, Conservation.

\section{Introduction}

The franciscana, Pontoporia blainvillei, is a small, endemic dolphin of the eastern coast of South America. It inhabits coastal waters from Espírito Santo in southeastern Brazil (Moreira and Siciliano, 1991) to Chubut Province, Argentina (Crespo et al.,1998). The species has been extensively captured in coastal gillnets throughout its range (e.g. Perez-Macri and Crespo, 1989; Praderi et al., 1989; Corcuera, 1994; Pinedo, 1994; Secchi et al., 1997; Di Beneditto et al., 1998). Given its coastal distribution, within $30 \mathrm{~m}$ of depth, the franciscana is vulnerable to most gillnet fisheries operating close to shore (e.g. Praderi et al., 1989; Corcuera, 1994; Secchi et al., 1997).

The occurrence of the franciscana has been reported along the São Paulo State coast for over 40 years (e.g. Carvalho, 1961; Schmiegelow, 1990; Santos and Siciliano, 1994; Higa et al., 1998; Santos et al., 2002). Some authors have suggested that fishery interactions are an important source of mortality for the species in this region (e.g. Carvalho, 1961; Siciliano, 1994). However, systematic and effective monitoring of the fisheries with the purpose of evaluating cetacean mortality has begun only recently in the central and southern coasts of São Paulo (Rosas, 2000; this study).

Fish production along the coast of São Paulo is important on a regional basis and corresponds to about $20 \%$ of the national production, as indicated by the Secretaria de Agricultura e Abastecimento (1989) and the Brazilian Environmental Agency
(IBAMA, 1997). Both industrial and artisanal fisheries take place in the area. Landing monitoring focuses on the former. The 1995 statistics suggests that total production of the industrial fishery accounts for about 35 thousand tones (IBAMA, 1997). On the other hand, the artisanal fishery is poorly known and there are no reliable statistics on its production. Castello et al. (1994) estimated that it corresponds to about $10 \%$ of the industrial fleet production.

Since August 1998, the artisanal fishing community of northern Praia Grande $\left(24^{\circ} 00^{\prime} \mathrm{S}, 46^{\circ} 24^{\prime} \mathrm{W}\right)$ has been monitored in order to describe the fishery and to evaluate incidental captures of small cetaceans and turtles. This paper summarizes fleet and gear characteristics as well as information on the mortality of franciscanas.

\section{Material and Methods}

\section{Study Area}

Praia Grande is located at Baixada Santista, in the central coast of São Paulo State (Figure 1). It is bordered by the cities of São Vicente and Mongaguá. There is only one $24 \mathrm{~km}$ long and flat sandy beach. Its topography is uniform and the slope is smooth. On average, the $30 \mathrm{~m}$ isobath is found about 13.5 nautical miles (nm) offshore. The most important freshwater runoff comes from the Itanhaém River, located in the southern part of the beach; freshwater input is considered moderate in this region (FUNDESPA, 1999). 


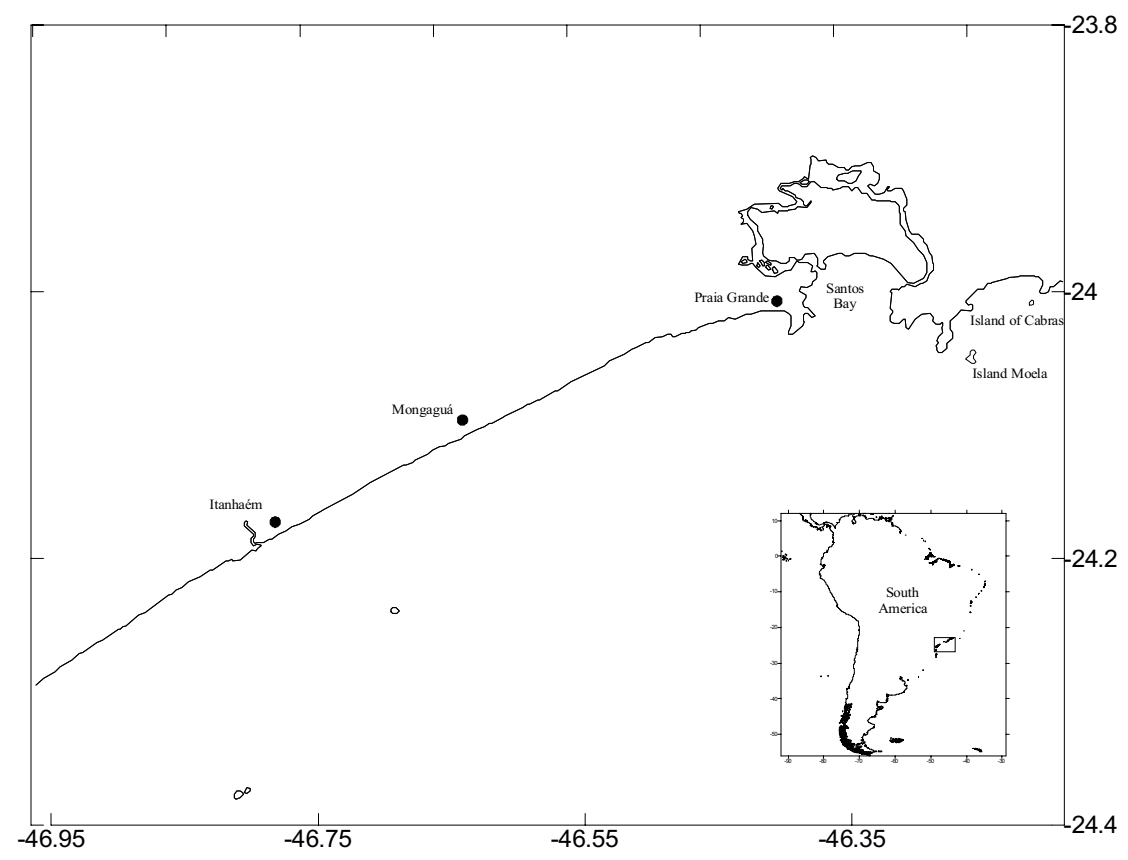

Figure 1. Study area - central São Paulo State coast $($ lat $=\mathrm{S}$, long $=\mathrm{W})$.

\section{Fishery Monitoring}

The fishing community of Praia Grande was systematically monitored through interviews in the landing port, a place known as 'Boutique de Peixes', or through onboard observations. Interviews were carried out three times per week, while onboard observations were conducted at least twice per month. All fishing boats were monitored at least once. Data on fishing gear and boat characteristics, fishing grounds, target species and information on incidental mortality of non-target species were collected as recommended by the International Whaling Commission (IWC, 1994; Annex E).

The relative small size of the fleet operating in the area allowed all fishing boats $(n=6)$ to be monitored. Therefore the number of franciscana catches recorded in this study is considered absolute for the area and period the fishery was monitored. Franciscana specimens collected were measured, dissected and sampled according to Norris (1961) and to Geraci and Lounsbury (1993). Biological samples (gonads, stomachs, teeth, skeleton, and tissue for genetic, contaminant and histopathology analysis) were deposited at the Instituto de Biociências, Faculdade de Medicina Veterinária and Museu de Zoologia, Universidade de São Paulo.

In order to investigate the catch composition of the commercially valuable (target) species, gillnet and beach seine landings were monitored and the fish were identified to the lower taxa according to field guides (Figueiredo, 1977; Figueiredo and Menezes, 1978, 1980, 2000; Menezes and Figueiredo, 1980, 1985).

\section{Fishing Effort and CPUE calculations}

Total and seasonal fishing efforts for two years combined (July 1999 to June 2001) were calculated for five gillnet types.
Nets known as 'feiticeira' and 'linguado' are not considered in effort calculations because their use is occasional in Praia Grande (Table 1). These nets are small, limited to some boats (three for 'feiticeira' and one for 'linguado') and they are used for short periods of time (usually a couple of months and only when the target species [mullets (Mugil spp.) and flat fish (Paralichthyidae)] occur in the area). In addition, franciscana captures have not been observed in these types of net. Effort for beach seine nets was also not calculated because they are not comparable to gillnets and because they are not considered a significant source of franciscana mortality (see below). Data from August 1998 to June 1999 were not included in the effort analysis because this period was used to adjust the sampling methodology.

Effort was calculated as a function of the length of the net and the soaking time (hrs/day) and was expressed as $\mathrm{km}$ of net $x$ day. Franciscana catch per unit of effort was expressed as number of dolphins captured $x 1000(\mathrm{~km} \text { of net } x \text { day })^{-1}$.

\section{Results}

Description of the Fishery

\section{Fishing area}

Fishermen from Praia Grande operate on a stretch of $31 \mathrm{~km}$ along the coast from Mongaguá to Guarujá (Figure 1). The fleet's range is small and therefore the fishery is limited to coastal areas within the $20 \mathrm{~m}$ isobath (i.e. about $7 \mathrm{~nm}$ offshore).

\section{Fleet and gear characteristics}

Approximately 20 fishermen work at the fishing community of northern Praia Grande. There are five aluminum boats (length $=5.8-6.8 \mathrm{~m}$ ) with $40 \mathrm{Hp}$ outboard engines and another wooden boat (length $=7.8 \mathrm{~m}$ ) with an $18 \mathrm{Hp}$ center engine. The boats do not have any navigation equipment. 
Table 1. Net characteristics and target species of the fishing gear used by the fleet operating from Praia Grande.

\begin{tabular}{|c|c|c|c|c|c|c|c|c|}
\hline \multirow[b]{2}{*}{ Type of net } & \multicolumn{7}{|c|}{ Gillnets } & \multirow{2}{*}{$\frac{\text { Beach seine net }}{\text { Arrastão }}$} \\
\hline & Pescada & Malhão & Malha 12 & Malha 14 & Boeira & Feiticeira & Linguado & \\
\hline Length (panels ${ }^{1}$ ) & $8-30$ & $2-6$ & $2-20$ & $2-20$ & $4-15$ & $1-6$ & 1 & $4-10$ \\
\hline Mesh size $(\mathrm{cm})$ & 7 & 15 or 16 & 12 & 14 & 10 or 11 & 11 and $30^{2}$ & 18 or 22 & 10 or 14 \\
\hline Height (m) & 1.6 & 7.4 & 2.8 & 3.3 & 10 & 3.6 & 1.5 & 5 \\
\hline Twine size (mm) & 40 & 120 & 60 & 60 & 50 & 50 & 50 & 60 or 100 \\
\hline $\begin{array}{l}\text { Position in the } \\
\text { water }\end{array}$ & bottom & surface & bottom & bottom & Surface & surface & bottom & beach seine \\
\hline Target species & $\begin{array}{l}\text { pescada } \\
\text { amarela }\end{array}$ & robalo & corvina & corvina & $\begin{array}{l}\text { cação, } \\
\text { cavala }\end{array}$ & tainha & linguado & robalo \\
\hline
\end{tabular}

${ }^{1}$ panel length $=60 \mathrm{~m}$.

${ }^{2}$ the feiticeira net is composed by three overlaid nets. Mesh sizes are $30 \mathrm{~cm}$ in the outer nets and $11 \mathrm{~cm}$ in the inner net.

The nets are set by two to three fishermen onboard each boat. A total of seven types of monofilament gillnet and one type of beach seine net are used. All boats operate more than one, usually several different types of fishing nets. Characteristics of each net type are summarized in Table 1. Net utilization depends on target species and weather conditions. Net type 'boeira' can be either fixed at the bottom with anchors or left adrift (an operation locally known as 'caceio'). If fixed, the nets are hauled out twice a day, usually at sunrise and sunset. On average, fixed nets are soaked for about $22 \mathrm{hrs}$ each day. During 'caceio' operations, the nets are escorted by the boats and stay in the water for 1 to $8 \mathrm{hrs}$ per day. Net types 'malha $12^{\prime}$, 'malha 14 ' and 'pescada' are bottom set nets while net types 'malhão' and 'boeira' are set at the surface. The former three nets are usually set farther away from the coast, while the surface nets are set up after the wave-breaking zone, usually in depths ranging from 8 to $12 \mathrm{~m}$.

\section{Variation in fishing effort}

The fishery in Praia Grande operates throughout the year. Net types used vary according to the season and the target species. Figure 2 summarizes seasonal fishing effort for five gillnet types.

Total gillnet effort in Praia Grande is higher in spring, followed by summer, winter and autumn. Bottom nets account for the majority $(82 \%)$ of the effort. The most substantial variation is observed for the net type 'boeira', for which effort is higher in fall and winter. Effort peaks in spring for net type 'malha 12', and in summer for nets type 'pescada', 'malhão' and 'malha 14'.

\section{Target species}

A total of 58 fish species of 29 families are taken in the fishery off Praia Grande. Target species for each net type are listed in Table 1 and the most important species in the catches are listed in Table 2
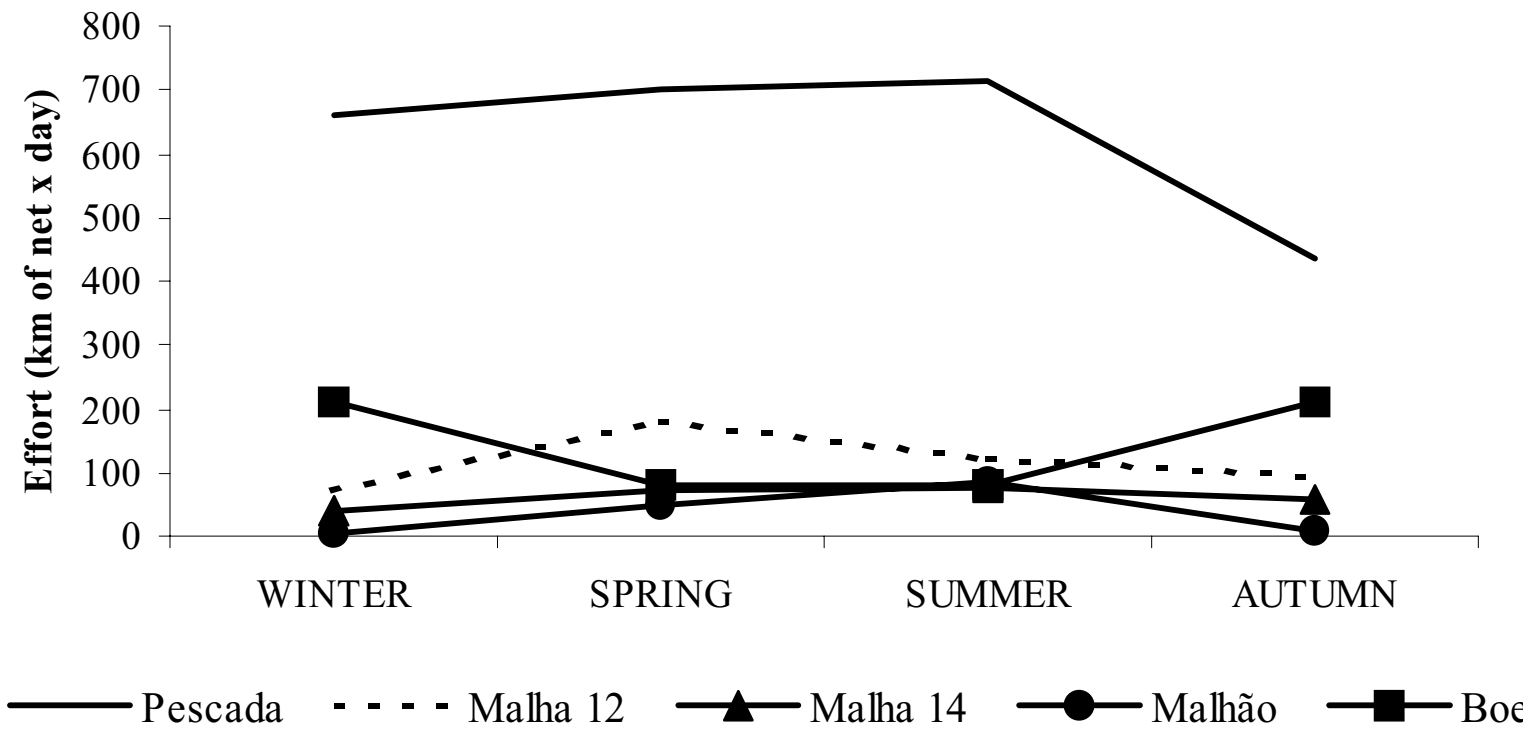

Figure 2. Seasonal fishing effort (km of net $\mathrm{x}$ day) for gillnets used by the Praia Grande fleet. 
Table 2. Most important fish species exploited by the fishery of Praia Grande.

\begin{tabular}{|c|c|c|}
\hline Family & Species & Local name \\
\hline \multirow[t]{4}{*}{ Sciaenidae } & Macrodon ancylodon & Pescada amarela \\
\hline & Micropogonias furnieri & Corvina \\
\hline & Menticirrhus littoralis & Betara, papa-terra \\
\hline & Larimus breviceps & Oveva \\
\hline Carangidae & Oligoplites spp. & Guaivira \\
\hline \multirow[t]{2}{*}{ Carcharhinidae } & Rizoprionodon porosus & Cação \\
\hline & Rizoprionodon lalandei & Cação \\
\hline Trichiuridae & Trichiurus lepturus & Espada \\
\hline \multirow[t]{4}{*}{ Ariidae } & Genidens genidens & Bagre \\
\hline & Bagre bagre & Bagre \\
\hline & Sciadeichthys luniscutis & Bagre \\
\hline & Catharops spixii & Bagre \\
\hline Scombridae & Scomberomorus brasiliensis & Sororoca, cavala \\
\hline Pomatomidae & Pomatomus saltator & Anchova \\
\hline Mugilidae & Mugil spp. & Tainha \\
\hline \multirow[t]{2}{*}{ Centropomidae } & Centropomus mexicanus & Robalo \\
\hline & Centropomus undecimalis & Robalo \\
\hline Paralichthyidae & - & Linguado \\
\hline Sphyrnidae & Sphyrna spp. & Cação martelo \\
\hline
\end{tabular}

Fishery Interactions

\section{Franciscana mortality}

The franciscana was the only cetacean species incidentally killed by the fishing fleet of Praia Grande. A total of 34 individuals were captured since August 1998. Three individuals were found alive, entangled together in a beach seine net, and were released alive. Fishermen reported that this was the first time they captured franciscanas in this type of net. The remaining 31 individuals were found dead in gillnets. Franciscanas were captured in all types of gillnets, excluding the 'feiticeira' and the 'linguado' nets. Mortality was higher in net type 'boeira' when absolute numbers are considered (Figure 3). Franciscana bycatch was recorded in every season. Captures involved from one to three individuals. Thirteen specimens were collected, eight males (measuring 106-122cm) and five females (71$134 \mathrm{~cm})$. Sex ratio is not significantly different from parity $\left(\chi^{2}=0.692, \mathrm{df}=1, \mathrm{p}>0.5\right)$. The range of lengths suggests that both juvenile and mature dolphins are taken. One $134 \mathrm{~cm}$ female, captured in August 2000, was pregnant with a $35 \mathrm{~cm}$ long fetus.

Dolphins were captured from close to shore (shallow waters) to depths of up to $20 \mathrm{~m}$. Twenty-eight dolphins $(82.4 \%)$ were captured near (within $7 \mathrm{~nm}$ of) Praia Grande, where effort is higher. The remaining dolphins were taken around Moela and Cabras Islands (see Figure 1).

There is no evidence to suggest that franciscanas are intentionally taken in Praia Grande. The species has no commercial value and is not used as bait or for human or animal consumption. Incidentally killed dolphins are thrown overboard when the fishermen do not bring them for research purposes or when no observers are present. During the period of this study, $58 \%$ of the franciscana captures reported were discarded at sea.

\section{CPUE analysis}

Catch per unit of effort (CPUE) analysis was obtained for two years when a total of 20 franciscanas were recorded. CPUE values for both years combined suggest that franciscana mortality is higher in net types 'malha 14 ' and 'boeira' (Figure 4). Seasonal variation in CPUE showed that franciscana mortality is higher in summer and autumn (Figure 4). No incidental captures were recorded in spring during the period in which CPUE was calculated, although captures in this season were previously observed.

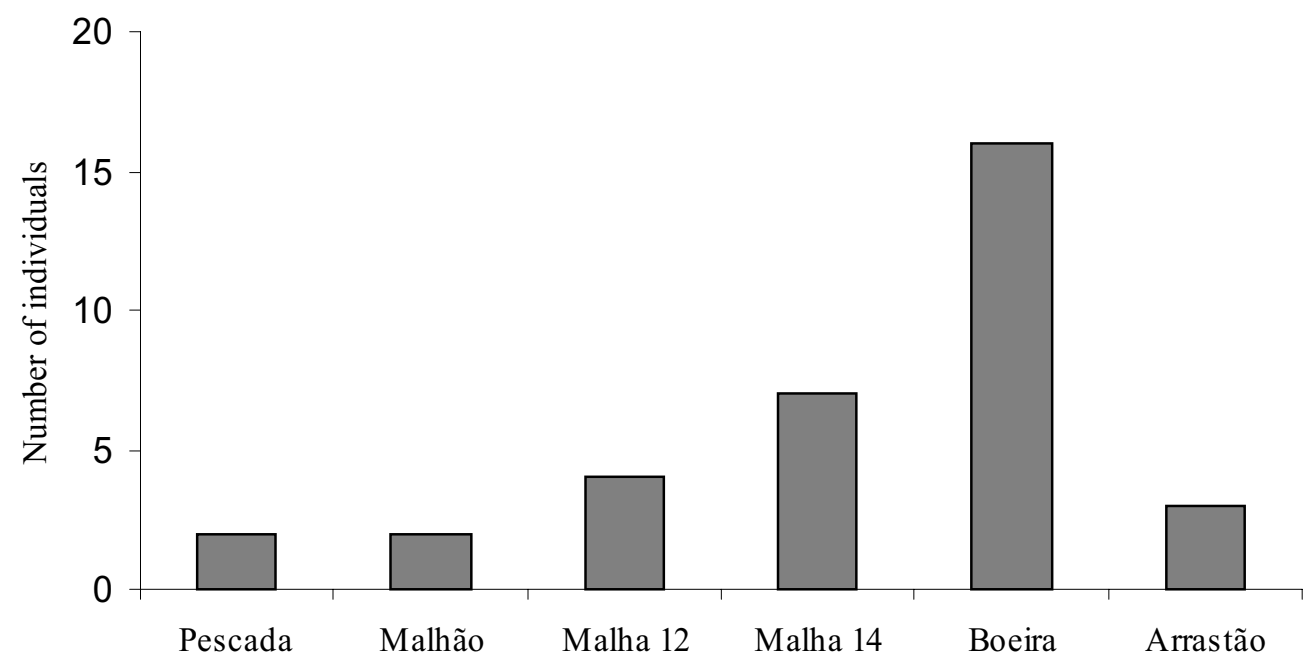

Figure 3. Franciscana captures in each type of net off Praia Grande. 


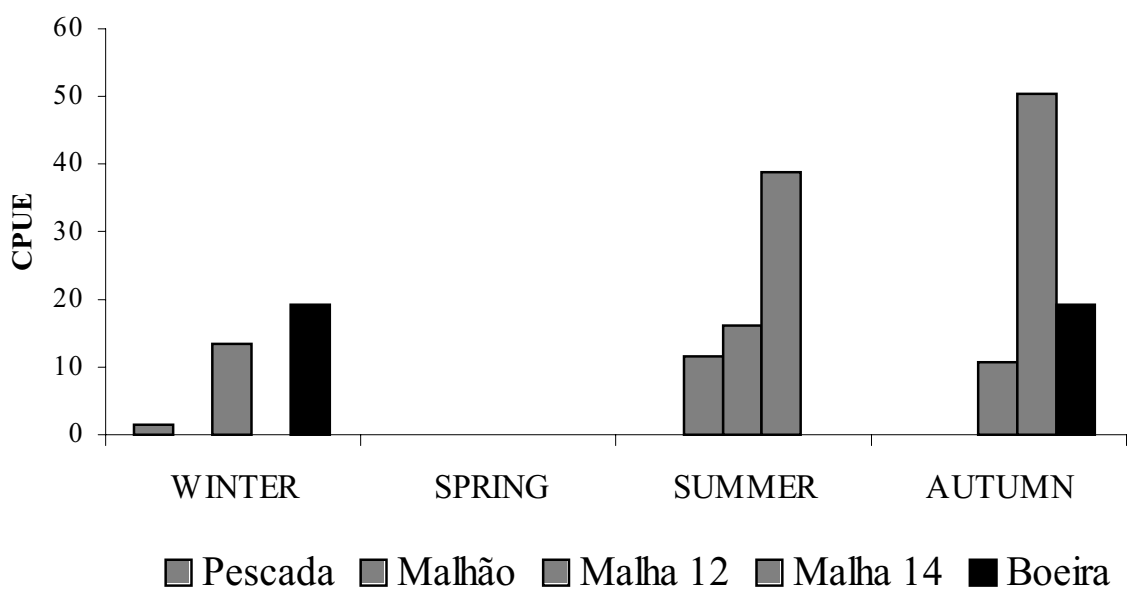

Figure 4. Seasonal catch per unit of effort (CPUE) of franciscanas for each net type used in the Praia Grande fishery.

\section{Discussion}

\section{Franciscana Fishery Interactions in Praia Grande}

The fishery in Praia Grande is essentially artisanal. Fishermen operate small, non-equipped boats very close to shore. The utilization of the different types of nets is subject of environmental conditions and fish availability; fishing effort is strongly dependent on weather conditions. It is then important to point out that franciscana mortality might be subject to temporal fluctuations. In 'good' years, where weather conditions are favorable and more suitable for fishing, more individuals will be captured if compared to 'bad' years. For this reason, only a regular and long term monitoring will allow accurate observations of the fluctuation levels.

Franciscanas were captured in five types of gillnets and one beach seine net. Apparently, the latter is a rare event and may not represent a threat to the species. Gillnets are a potential threat and an important source of mortality. In this study, franciscana captures were observed in both bottom and surface set gillnets. Gillnet mesh sizes of Praia Grande are relatively small $(7-16 \mathrm{~cm})$, similar to the ones used in other areas where franciscana mortality is also high (Moreno et al., 1997; Secchi et al., 1997; Zanelatto, 1997; Rosas, 2000). Larger mesh sizes of up to $40 \mathrm{~cm}$ were used in other regions such as Uruguay and Argentina (Crespo et al., 1986; Perez-Macri and Crespo, 1989; Praderi et al., 1989). This suggests that mesh size may not influence franciscana mortality rates (see also Corcuera, 1994). Fishing area and season are likely to be more important factors influencing franciscana captures; however, it is unknown whether this sample is representative.

Franciscanas were not captured in 'feiticeira' and 'linguado' net types possibly by chance. During this study, these nets were only used for short periods of time and by few fishermen in Praia Grande. Nets with similar characteristics are known to catch franciscanas in northern Rio Grande do Sul and Paraná states, Brazil (Moreno et al., 1997; Zanelatto, 1997). CPUE analysis revealed that the bottom-set net type 'malha 14' and surface net type 'boeira' appear to catch the most franciscanas. CPUE values of 'boeira' type net were higher in seasons in which effort was also higher: winter and autumn. CPUE for net type 'malha 14 ' was greater in summer and autumn. If the area of the net, rather than the length, was used as unit of effort, CPUE would have been higher for net type 'malha 14 ' than for 'boeira'. This is explained by the substantial difference in the height of these two types of net.

Although CPUE data suggest that franciscanas may be more vulnerable to bottom set gillnets, no conclusions can be reached until further information on the seasonal and spatial distribution of the nets are obtained. It is likely that other factors may be contributing to a larger CPUE for bottom set gillnets. The surface-set net 'boeira' is usually set up closer to shore where depth varies from 8 to $12 \mathrm{~m}$, while bottom set gillnets are used in deeper waters. If franciscana's density is higher further away from shore, it is possible that CPUE reflects differences in density as a function of distance from shore rather than vulnerability to a given net type.

The CPUE observed for some areas within the range of the franciscana (Table 3) suggests that values observed for Praia Grande are similar to those recorded in other areas of Brazil and Uruguay. While these figures could reflect the relative abundance of the franciscana in different areas, it is important to emphasize that direct comparison CPUE values must be made with caution, given possible spatial and temporal differences in data collection and fishing areas, franciscana's distribution and abundance, or other unknown factors. This highlights the importance of standardizing the collection of effort data. This is particularly important for areas where fishing gear and methods are similar and therefore comparable. This might be the case of the fishing communities distributed along the coast of Santa Catarina, Paraná and São Paulo states.

\section{Lessons from Monitoring Praia Grande Fishery}

Progress in the stock identity of the franciscana has been taking place. Pinedo (1991) examined morphological characteristics and suggested the existence of two different geographical forms differentiated into 'northern' (dolphins 
distributed from $22^{\circ}-27^{\circ} S$ ) and 'southern' $\left(32^{\circ}-38^{\circ} S\right)$ forms. Secchi et al. (1998) examined mitochondrial DNA from individuals of these two forms and also found significant differences between them. Both studies suggested that the two populations should be treated as separate management units. More recently, distributional, demographic, ecological and biological data, including genetics, led to the establishment of four areas ('Franciscana Management Areas - FMA'), which were proposed for management purposes (Secchi et al, in press). FMA II corresponds to the states of Santa Catarina, Paraná and São Paulo. While fishery monitoring and bycatch estimates have been obtained for other areas (e.g. FMA I [Di Beneditto et al., 1998]; FMA III [Moreno et al., 1997; Praderi, 1997; Secchi et al., 1997; Kinas and Secchi, 1998] and FMA IV [Corcuera, 1994; Corcuera et al., 1994; Cappozzo et al., 2000]), information for FMA II is scarce and limited to small geographic areas (e.g. Zanelatto, 1997; Rosas, 2000).

The study carried out in Praia Grande provides insights regarding fishery and cetacean bycatch monitoring that have important implications for improving the knowledge, and therefore conservation efforts, of the franciscana in FMA II. In Praia Grande, fishermen operate throughout the year in a relatively small fishing ground. There is a wide range of fishing gear and a substantial variability in the fishing season and effort for each net type. Similar fishing communities can be found along a large portion of southern and southeastern Brazil (e.g. Tiago et al., 1995; Zanelatto, 1997; Rosas, 2000). For example, Zanellato (1997) identified 47 small fishing villages along the coast of Paraná State and Simões-Lopes and Ximenez (1993) reported that some are found along the coast of the State of Santa Catarina. Similar communities along the coast of São Paulo State (e.g. Itanhaém, Mongaguá, Guarujá, Bertioga, São Sebastião, Caraguatatuba and Ubatuba) were also observed. The characteristics of these fishing communities suggest that the fishing grounds are restricted to small geographic areas, probably extending to a few dozen miles away from the landing locations. This indicates that, given the relatively low fishing effort, the absolute number of franciscanas taken by each community alone is probably small. However, assuming that franciscana bycatch levels are similar among these fishing communities and considering that these communities are spread out along an important stretch of the coast, it is likely that the combined franciscana mortality is substantial. Therefore, it is possible that bycatch from small fishing villages combined represents a threat to the franciscana in southern and southeastern Brazil. Corcuera (1994) showed that combined mortality estimates for fishing camps in Provincia de Buenos Aires, Argentina, were substantial.
The spatial distribution of the franciscana in southeastern Brazil is poorly known but in other areas the species is known to be common in depths of up to $30 \mathrm{~m}$ (e.g. Pinedo et al., 1989). The fact that the fishery in Praia Grande does not take place in deeper waters (distance from shore further than $7 \mathrm{~nm}$ and deeper than $20 \mathrm{~m}$ ) is an important factor in the conservation of the franciscana because a portion of its area of distribution is left out of the fishing grounds. While this might be true for Praia Grande, the area of operation of fishing fleets from other villages must be confirmed before the bycatch can be ascertained. Variation between fishing areas has previously been reported by Rosas (2000), who reported that fleets from Paraná State operate within $5 \mathrm{~nm}$ from shore, while boats from Cananéia (southern São Paulo State) usually fish between 15 and 40nm from shore.

The scenario presented above makes clear the urgent need for an assessment of the number of local fishing communities followed by an evaluation of the fishery characteristics and bycatch levels in unmonitored areas off southern and southeastern Brazil (FMA II). This is imperative to obtain accurate estimates of franciscana mortality. It is also clear that monitoring must be continuous and developed on a long-term basis because of the variability in fishing effort. Unfortunately, there is little information on franciscana distribution and habitat requirements. Such data are urgently required to determine the impacts of any fishing-related mortalities.

\section{Conclusions and Recommendations}

1) The Praia Grande fishery is artisanal and effort is greatly affected by weather conditions. Fishing grounds correspond to a small geographic area and fishing takes place relatively close to shore. The franciscana was the only cetacean species incidentally captured by the fishing fleet operating from Praia Grande. Individuals of both sexes and reproductive status were observed. Captures were recorded throughout the year, but CPUE data revealed that they reach a peak in the summer and fall. Mortality was higher in bottom set gillnet 'malha 14'. Dolphins have no commercial or consumption value and are discarded at sea. Monitoring of the fishery in Praia Grande should continue on a long-term basis in order to: 1) estimate franciscana bycatch levels; 2) collect specimens for life-history, stock identity, and biological studies; 3) determine the spatial distribution of the fishing nets and areas of higher mortality; 4) investigate capture probabilities in the different types of gillnets; 5) understand fluctuations in fishing operations due to

Table 3. Annual Catch per Unit of Effort (CPUE) values [dolphins $x 1000 \times(\mathrm{km} \text { of net } \mathrm{x} \text { day })^{-1}$ ] observed for different areas along the distribution of the franciscana.

\begin{tabular}{lccl}
\hline \hline Region & Period & CPUE & Source \\
\hline \hline Northern Rio de Janeiro, Brazil & $1987-1996$ & $2.7-7.7$ & Di Beneditto et al., 1998 \\
Praia Grande, São Paulo, Brazil & $1999-2001$ & 5.0 & This study \\
Southern Rio Grande do Sul, Brazil & 1994 & 6.6 & Secchi et al., 1997 \\
Uruguay & $1975-78 ; 1980-82$ & $2.3-5.6$ & Crespo et al., 1986 \\
\hline \hline
\end{tabular}


environmental variables; and 6) investigate the economics of the fishery in order to understand its cost-benefit relationships.

2) The fishery at Praia Grande is an example of the several small fishing communities spread along the southeastern and southern coasts of Brazil. Considering that these communities operate in a similar way and assuming that levels of franciscana mortality are comparable, they may represent a threat to the species. An assessment of the fishing villages and the characteristics of the fishery are therefore necessary, along with an evaluation of the franciscana (and other cetacean) mortality. It is subsequently recommended that research be expanded or initiated in other areas along FMA II. As monitoring small fishing villages is intrinsically difficult and requires substantial effort, it is likely that cooperative work involving several research groups, covering different geographic areas and using standardized methodology will be most effective.

\section{Acknowledgements}

The authors wish to thank all the fishermen from 'Boutique de Peixes' for their help, goodwill and interest. The manuscript was greatly improved by comments and suggestions provided by Enrique Crespo, Daniel Danilewicz, Vic Peddemors and Eduardo Secchi. Erica Barbosa was helpful whenever we needed her assistance. Juliana Marigo and Valéria Ruoppolo helped collecting franciscana dolphins and assisted with the necropsies. The staff of Instituto de Biociências and Instituto Oceanográfico, Universidade de São Paulo, provided logistical support and storing facilities. We also acknowledge Dr. Mário Katsuragawa for his encouragement. CPB has been financially supported by Fundação de Amparo à Pesquisa do Estado de São Paulo (FAPESP, processo 00/02537-1) and ANZ has been funded by Conselho Nacional de Desenvolvimento Científico e Tecnológico $(\mathrm{CNPq}$, processo 200285/98-0). This study was carried out under IBAMA permits no. 068/99-DIFAS and 209/2000- DIFAS.

\section{References}

Cappozzo, H.L., Monzón., F., Perez, J.E., Albareda, D. and Corcuera, J. (2000) Mortalidad del delfín franciscana (Pontoporia blainvillei) en la Provincia de Buenos Aires. Technical Paper DT24 presented to the IV Workshop para a Coordenação da Pesquisa e Conservação da Franciscana, Pontoporia blainvillei, no Atlântico Sul Ocidental, 05-09 November, 2000, Porto Alegre.

Carvalho, C.T. (1961) "Stenodelphis blainvillei" na costa meridional do Brasil, com notas osteológicas (Cetacea: Platanistidae). Revista Brasileira de Biologia 21(4): 443-454.

Castello, J.P., Yamaguti, N., Corrêa, M.F.M. and Ledo, B.S. (1994) Diagnóstico ambiental Oceânico e costeiro das regiões sul e sudeste do Brasil. Oceanografia Biológica: Nécton. Vol. V. FUNDESPA/PETROBRÁS. 472pp.

Corcuera, J. (1994) Incidental mortality of franciscanas in Argentine waters: the threat of small fishing camps. Pages 291-294 in Perrin, W.F., Donovan, G.P. and Barlow, J. (Eds) Gillnets and cetaceans. International Whaling Commission (special issue 15), Cambrige.

Corcuera, J., Monzón, F., Crespo, E.A., Aguilar, A. and Raga, J.A. (1994) Interactions between marine mammals and the coastal fisheries of Necochea and Claromecó (Buenos Aires, Argentina). Pages 283-290 in Perrin, W.F., Donovan, G.P. and Barlow, J. (Eds) Gillnets and cetaceans. International Whaling Commission (special issue 15), Cambridge.

Crespo, E.A., Pérez Macri, G. and Praderi, R. (1986) Estado actual de la poblacion de franciscana (Pontoporia blainvillei) en las costas Uruguayas. Pages 92-105 in Actas, I Reunion de Trabajo de Expertos en Mamiferos Acuaticos de America del Sur, 25-29 June 1984, Buenos Aires.

Crespo, E.A., Harris G. and González, R. (1998) Group size and distributional range of the franciscana, Pontoporia blainvillei. Marine Mammal Science 14: 845-849.

Di Beneditto, A.P.M., Ramos, R.M.A. and Lima, N.R.W. (1998) Fishing activity in northern Rio de Janeiro State (Brazil) and its relation with small cetaceans. Brazilian Archives of Biology and Technology 41(3): 296-302.

Figueiredo, J.L. (1977) Manual de peixes marinhos do sudeste do Brasil. I. Introdução. Cações, raias e quimeras. Editora Edusp, São Paulo.

Figueiredo, J.L. and Menezes, N.A. (1978) Manual de peixes marinhos do sudeste do Brasil. II Teleostei (1). Editora Edusp, São Paulo.

Figueiredo, J.L. and Menezes, N.A. (1980) Manual de peixes marinhos do sudeste do Brasil. III Teleostei (2). Editora Edusp, São Paulo.

Figueiredo, J.L. and Menezes, N.A. (2000) Manual de peixes marinhos do sudeste do Brasil. VI Teleostei (5). Editora Edusp, São Paulo.

FUNDESPA (1999) Levantamento oceanográfico da área diretamente afetada por efluentes dos emissários submarinos de esgotos da Sabesp, ente os munícipios de São Sebastião e Mongaguá, Estado de São Paulo. Relatório final (vol. I). 170pp.

Geraci, J.R. and Lounsbury, V.J. (1993) Marine mammals ashore: A field guide for strandings. Texas A\&M Sea Grant Publications, Galveston.

Higa, A., Sousa, L. De, Zerbini, A.N., Radwanski, A.E. and Mello, G.P.M.B. (1998) Encalhes de cetáceos em Ubatuba, litoral norte de São Paulo: Dezembro/1996 a março/1998. Page 98 in Anais, VIII Reunião de Especialistas em Mamíferos Aquáticos da América do Sul, 25-29 October 1998, Olinda.

IBAMA (1997) Estatística da pesca - 1995 - Grandes regiões e unidades da federação. Ministério do Meio Ambiente, dos Recursos Hídricos e da Amazônia Legal, Brasília. 97pp.

IWC (1994) Report of the Scientific Committee. Reports of the International Whaling Commission (special Issue 15): 1-72.

Kinas, P.G. and Secchi, E.R. (1998) Modeling truncated data to estimate incidental kills of franciscana, Pontoporia blainvillei, by gillnets. Report of the International Whaling Commission 48: 533-536.

Menezes, N.A. and Figueiredo, J.L. (1980) Manual de peixes marinhos do Sudeste do Brasil. IV. Teleostei (3). Editora Edusp, São Paulo.

Menezes, N.A. and Figueiredo, J.L. (1985) Manual de peixes marinhos do Sudeste do Brasil. V. Teleostei (4). Editora Edusp, São Paulo.

Moreira, L.M. de P. and Siciliano S. (1991) Northward extension range for Pontoporia blainvillei. Page 48 in Resumos, IX Biennial Conference on the Biology of Marine Mammals, 5-9 December 1991, Chicago.

Moreno, I.B., Ott, P.H. and Danilewicz, D.S. (1997) Análise preliminar do impacto da pesca artesanal costeira sobre Pontoporia blainvillei no litoral norte do Rio Grande do Sul, sul do Brasil. Pages 31-41 in Pinedo, M.C. and Barreto, A.S. (Eds) Anais do $2^{\circ}$ Encontro sobre Coordenação de Pesquisa e Manejo da Franciscana. Ed. FURG, Rio Grande.

Norris, K.S. (1961) Standardized methods for measuring small cetaceans. Journal of Mammalogy 42(4): 471-476.

Perez-Macri, G. and Crespo, E.A. (1989) Survey of the franciscana, Pontoporia blainvillei, along the Argentine coast, with a preliminary evaluation of mortality in coastal fisheries. Pages 57-63 in Perrin, W.F., Brownell Jr., R.L., Zhou, K., and Jiankang, L. (Eds) Biology and conservation of the river dolphins. Occasional Papers. IUCN SSC 3. Gland. 
Pinedo, M.C., Praderi, R. and Brownell Jr., R.L. (1989) Review of the biology and status of the franciscana Pontoporia blainvillei (Gervais e D'Orbigny, 1844). Pages 46-51 in Perrin, W.F., Brownell Jr., R.L., Zhou, K., and Jiankang, L. (Eds) Biology and conservation of the river dolphins. Occasional Papers. IUCN SSC 3. Gland

Pinedo, M.C. (1991) Development and variation of the franciscana, Pontoporia blainvillei. PhD Thesis. University of California, Santa Cruz. 406pp.

Pinedo, M.C. (1994) Review of small cetacean fishery interactions in southern Brazil with special reference to the franciscana, Pontoporia blainvillei. Reports of the International Whaling Commission (special issue) 15: 251-260.

Praderi, R., Pinedo, M.C. and Crespo, E.A. (1989) Conservation and management of Pontoporia blainvillei in Uruguay, Brazil and Argentina. Pages 52-56 in Perrin, W.F., Brownell Jr., R.L., Zhou, K., and Jiankang, L. (Eds) Biology and conservation of river dolphins. Occasional Papers. IUCN SSC 3. Gland.

Praderi, R. (1997) Análisis comparativo de estadísticas de captura y mortalidad incidental de Pontoporia blainvillei em Uruguay durante 20 años. Pages 42-53 in Pinedo, M.C. and Barreto, A.S. (Eds) Anais do $2^{\circ}$ Encontro sobre Coordenação de Pesquisa e Manejo da Franciscana. Ed. FURG, Rio Grande.

Rosas, F.C.W. (2000) Interações com a pesca, mortalidade, idade, reprodução e crescimento de Sotalia guianensis e Pontoporia blainvillei (Cetacea, Delphinidade e Pontoporiidae) no litoral sul do Estado de São Paulo e litoral do Estado do Paraná, Brasil. PhD Thesis. Universidade Federal do Paraná, Curitiba. 145pp.

Santos, M.C. and Siciliano, S. (1994) Novos registros de cetáceos para o litoral do Estado de São Paulo - Brasil. Page 58 in Anais, VI Reunião de Especialistas em Mamíferos Aquáticos da América do Sul, 24-28 October 1994, Florianópolis.

Santos, M.C.O., Vicente, A.F.C., Zampirolli, E., Alvarenga, F. and Souza, S.P. (2002) Records of franciscana (Pontoporia blainvillei) from the coastal waters of São Paulo State, southeastern Brazil. Latin American Journal of Aquatic Mammals (special issue) 1: 169-174.
Schmiegelow, J.M.M. (1990) Estudo sobre cetáceos odontocetos encontrados em praias da região entre Iguape (SP) e Baía de Paranaguá (PR) $\left(24^{\circ} 42^{\prime} S-25^{\circ} 28^{\prime} S\right)$ com especial referência a Sotalia fluviatilis (Gervais, 1853) (Delphinidae). MSc Thesis. Universidade de São Paulo, São Paulo. 149pp.

Secchi, E.R., Zerbini, A.N., Bassoi, M., Dalla Rosa, L., Moller, L.M. and Rocha-Campos, C.C. (1997) Mortality of franciscanas, Pontoporia blainvillei, in coastal gillnetting in southern Brazil: period 1994-1995. Report of the International Whaling Commission 47: 653-658.

Secchi, E.R., Wang, J.Y., Murray, B., Rocha-Campos, C.C. and White, B.N. (1998) Population differentiation in the franciscana (Pontoporia blainvillei) from two geographic locations in Brazil as determined from mitochondrial DNA control region sequences. Canadian Journal of Zoology 76: 1622-1627.

Secchi, E.R., Danilewicz, D., and Ott, P.H. (in press) Applying the phylogeographic concept to identify franciscana dolphin stocks: implications to meet management objectives. Journal of Cetacean Research and Management.

Simões-Lopes, P.C. and Ximenez, A. (1993) Annotated list of the cetaceans of Santa Catarina coastal waters, southern Brazil. Biotemas 6(1): 67-92.

Secretaria de Agricultura e Abastecimento do Estado de São Paulo (1989) Plano Estadual da Pesca. Secretaria de Agricultura e Abastecimento do Estado de São Paulo, São Paulo. 183pp.

Siciliano, S. (1994) Review of small cetaceans and fishery interactions in coastal waters of Brazil. Reports of the International Whaling Commission (special issue) 15: 241-250.

Tiago, G.C., Tutui, S.L. dos S., von Seckendorff, R.W., Grassi, R.T.B. and Inácio, M.L. da S. (1995) Análise da frota pesqueira sediada em Ubatuba, Estado de São Paulo, Brasil. Boletim do Instituto de Pesca 22(2): 71-83.

Zanelatto, R.C. (1997) Captura acidental de toninha Pontoporia blainvillei Gervais \& D’Orbigny, 1844 (Cetacea, Pontoporiidae) no litoral do Estado do Paraná, Brasil. Pages 23-30 in Pinedo, M.C. and Barreto, A.S. (Eds) Anais do $2^{\circ}$ Encontro sobre Coordenação de Pesquisa e Manejo da Franciscana. Ed. FURG, Rio Grande. 